\title{
The Location Analysis on Dry Port of the Inland in Jinan City
}

\author{
Jianmeng Sun ${ }^{1, *}$, Haining Wang ${ }^{2}$ \\ ${ }^{1}$ Shandong Institute of Transportation Science, Jinan, Shandong 250023, China \\ ${ }^{2}$ Shandong Hi-speed Group Co., Ltd, Jinan, Shandong 250013, China
}

\begin{abstract}
The port competition is more and more intense, starts to be the initial infrastructure and the operation ability competition, now is in the port economy hinterland competition. Dry Port has the functions of customs declaration, forwarder, inspection and quarantine, warehousing, loading and unloading, circulation processing etc. At present, the construction and layout of the inland dry port, the possibility and feasibility of construction are the focus of the research. The location of dry port in Jinan is fully analyzed on the basis of reference to the advanced operation mode and development experience of the excellent nonwater port in the country and abroad. This paper first analyzed Location factors; Then center of gravity method were analyzed. Finally, the location of the dry port is determined.
\end{abstract}

\section{The factor analysis of the location of dry port in Jinan}

\subsection{Proximity to market principles}

The profitability of a dry port is usually dependent on the market. The choice of close to the market can effectively reduce the transport distance, reduce transshipment, avoid multiple loading and unloading, reduce freight, and timely replenishment. The price of land close to the market is higher than other places, so there are other factors that should be taken into consideration on dry port.

\subsection{Close to the transportation hub principle}

The transport facilities must be used for transport from the dry port to the port and from the port to the dry port. Fast and convenient transportation is also one of the factors to be considered.Site selection can quickly organize the delivery and purchase of goods in the more developed areas. It can also reduce the accumulation and retention of goods, improve the efficiency of logistics operation and improve the aging time.

\subsection{Choose low land price principle}

A dry port would normally choose a place with a lower land price. A dry port usually chooses a place close to the city. This can not only achieve the low cost of land, but also can make effective use of the city's developed traffic. It can comprehensively consider all aspects of the dry port to improve the efficiency.

\subsection{The principle of complete infrastructure}

\footnotetext{
$\overline{\text { * Corresponding author: mxr6465201@ } 126 . c o m}$
}

The construction and operation of a dry port cannot be separated from the water port infrastructure, but also requires considerable manpower, material resources and financial resources. The infrastructure generally covers an area of large area, with difficulty in recovery, large investment, long payback period, and difficult to relocate.If you have existing infrastructure you can reduce the amount of money invested and increase the revenue.

\section{The factor analysis of the location of dry port in Jinan}

\subsection{The relationship between the geographical location of dry port and city layout}

According to the geographical location of the site, the distribution of resources, the structure of the region, the distribution of the consumption market and so on have a decisive influence on the development of the waterless port. Dry port, therefore, to comprehensively consider the site selection of regional traffic, surrounding the market situation, port and dry port distance, the city's industry layout, avoid benefit back against the effect.

\subsection{The relationship between the construction address and transportation on the dry port}

The development of a city cannot be separated from the traffic, and the construction and development of dry port cannot be separated from the traffic. The ideal effect of transportation goods is low freight, fast speed, and the choice of a well-developed area can achieve the desired effect. Meanwhile, multi-modal transport tools and methods can be selected flexibly. Dry port construction site should also consider the pressure of urban traffic. 
Choose the right location to avoid reducing the benefit of the dry port.

\section{Model analysis of the center of gravity method}

Gravity model:

$$
\operatorname{MinTc}=\sum \text { ViRidi }=\sum \text { Cidi }
$$

In the formula:

$\mathrm{T}_{\mathrm{c}}$ - Total transportation cost (yuan);

$\mathrm{V}_{\mathrm{i}}$ - Transport capacity of I point (ton);

$\mathrm{R}_{\mathrm{i}}$ - Transport rate of I point (yuan/ton. $\mathrm{Km}$ );

$\mathrm{d}_{\mathrm{i}}$ - The distance from the location of the inland dry port

to I point $(\mathrm{km})$;

$\mathrm{C}_{\mathrm{i}}$ - The transportation cost to I point (yuan $/ \mathrm{km}$ ).

The location of the lowest cost of transportation coordinates $\mathrm{X}$ and $\mathrm{Y}$, gravity method using the formula is:

$$
\begin{aligned}
& X=\sum d i x V i / \sum V i \\
& Y=\sum d i y V i / \sum V i
\end{aligned}
$$

In the formula:

$\bar{X}$ - The x-coordinate of the center of gravity;

$y$

- The y-coordinate of the center of gravity;

$\boldsymbol{d}_{i x}$ _The $\mathrm{x}$-coordinate of point I;

$\boldsymbol{d}_{i y}$ _the y-coordinate of point I;

$V_{i}$ - The amount of goods shipped to or from I point.

The method of gravity is to calculate the location of the dry port according to the coordinates of each port. Other factors should be considered in the position of gravity. The actuality and candidate location of the land should be considered comprehensively. The position calculated according to the coordinates may be park, station and so on. So you have to think about other factors.

\section{The development of the counties and districts in Jinan and the location of the dry port}

\subsection{The economic operation of various counties and districts in Jinan in 2016}

The economic operation conditions of various counties and counties in Jinan in 2016 are shown in table 1.

As shown in table 1, in the various counties and districts of Jinan city in 2016, the total GDP of the Lixia District is the first. At the same time, in 2015, the region's GDP also ranked first. According to the GDP of dry port location, should be in lixia District, so that promotes the economic development of dry port, can provide affordable goods for dry port.

\subsection{The import and export of various counties in Jinan in 2016}

Evaluation In 2016, import and export situation of various prefectures in Jinan are shown in table 2.

As shown in table 2, in the various counties and districts of Jinan city, the total import and export volume of Lixia District is the first in 2016.Lixia District has an important position in the development of Jinan, control the economic lifeline of development of Jinan, only the total import and export in 2016 and the actual received foreign, the dry port should be constructed in the Lixia District.

\subsection{The situation of industrial development and investment on each county area in Jinan}

The industrial situation of each county in Jinan is shown in table 3.

As shown in table 3 , in the various counties and districts of Jinan city in 2016, the Lixia District in investment in fixed assets is the first. Zhangqiu District ranks first in the major business income of the above industries. The total amount of industrial profits in Zhangqiu District is the first in the county districts of Jinan. It should be constructed in Zhangqiu District when considering industrial factors to construct the

\begin{tabular}{|c|c|c|c|c|c|}
\hline \multirow[b]{2}{*}{ Precedence } & \multirow[b]{2}{*}{ Counties } & \multicolumn{2}{|c|}{$\begin{array}{c}\text { GDP } \\
\text { (the hundred million) }\end{array}$} & \multirow{2}{*}{$\begin{array}{c}\text { The incremental } \\
\text { (the hundred } \\
\text { million) }\end{array}$} & \multirow{2}{*}{$\begin{array}{c}\text { Nominal growth } \\
(\%)\end{array}$} \\
\hline & & In 2016 & In 2015 & & \\
\hline
\end{tabular}
inland dry port in Jinan.

Table 1. The GDP of counties and districts in Jinan in 2016 


\begin{tabular}{|c|c|c|c|c|c|}
\hline & $\begin{array}{c}\text { Jinan } \\
\text { City }\end{array}$ & 6536.12 & 6100.23 & 435.89 & 7.15 \\
\hline 1 & $\begin{array}{c}\text { Lixia } \\
\text { District }\end{array}$ & 1837.1 & 1667.0 & 170.1 & 10.20 \\
\hline$\#$ & High-tech zone & 650.3 & 596.3 & 54.0 & 9.06 \\
\hline 2 & Zhangqiu District & 924.9 & 870.8 & 54.1 & 6.21 \\
\hline 3 & Licheng District & 868.8 & 808.0 & 60.8 & 7.52 \\
\hline 4 & Shizhong District & 826.9 & 751.3 & 75.6 & 10.06 \\
\hline 5 & Huaiyin District & 431.9 & 387.1 & 44.8 & 11.57 \\
\hline 6 & Tianqiao District & 418.0 & 384.9 & 33.1 & 8.60 \\
\hline 7 & Jiyang County & 295.0 & 276.3 & 18.7 & 6.77 \\
\hline 8 & Changqing District & 289.4 & 265.2 & 24.2 & 9.13 \\
\hline 9 & Pingyin County & 245.2 & 227.0 & 18.2 & 8.02 \\
\hline 10 & Shanghe County & 179.2 & 165.7 & 13.5 & 8.15 \\
\hline & urban area & 5597.0 & 5134.3 & 462.7 & 9.01 \\
\hline & counties & 719.4 & 669.0 & 50.4 & 7.53 \\
\hline & total & 6316.4 & 5803.3 & 513.1 & 8.84 \\
\hline
\end{tabular}

Table 2. Import and export situation of counties in Jinan in 2016

\begin{tabular}{|c|c|c|c|c|c|c|}
\hline \multirow{2}{*}{ Counties } & \multicolumn{2}{|c|}{$\begin{array}{c}\text { Total retail sales of consumer } \\
\text { goods(the hundred million ) }\end{array}$} & \multicolumn{2}{c|}{$\begin{array}{r}\text { Total import and export (the } \\
\text { hundred million ) }\end{array}$} & $\begin{array}{c}\text { Actual to account foreign } \\
\text { capital (the hundred } \\
\text { million ) }\end{array}$ \\
\cline { 2 - 7 } & $1-12$ month & $\begin{array}{c}\text { The cumulative } \\
\text { year-on-year\% }\end{array}$ & $1-12$ month & $\begin{array}{c}\text { The } \\
\text { cumulative } \\
\text { year-on- } \\
\text { year\% }\end{array}$ & $\begin{array}{c}1-12 \\
\text { month }\end{array}$ & $\begin{array}{c}\text { The } \\
\text { cumulative } \\
\text { year-on- } \\
\text { year\% }\end{array}$ \\
\hline Total & & & & 13.0 & 112.3 & 14.7 \\
\hline Lixia District & 915.2 & 10.4 & 75.8 & 5.0 & 19.3 & 15.2 \\
\hline Shizhong District & 484.6 & 10.2 & 31.7 & 17.7 & 15.4 & 12.7 \\
\hline Huaigin District & 479.2 & 10.4 & 33.3 & 15.4 & 3.5 & 57.5 \\
\hline Tianqiao District & 408.7 & 10.5 & 26.8 & 8.5 & 2.3 & 19.1 \\
\hline Licheng District & 519.6 & 9.5 & 106.4 & -11.9 & 10.3 & 16.9 \\
\hline Changqing District & 137.9 & 10.9 & 6.7 & 23.0 & 8.1 & 0.0 \\
\hline Pingyin County & 96.3 & 11.2 & 45.2 & 5.1 & 1.5 & 42.1 \\
\hline Jiyang County & 125.9 & 10.8 & 18.7 & 2.6 & 5.6 & 12.1 \\
\hline Shanghe County & 88.8 & 11.2 & 7.3 & 9.1 & 3.1 & 12.7 \\
\hline Zhangqiu District & 390.4 & 11.1 & 58.0 & -2.1 & 14.9 & 10.5 \\
\hline High-tech zone & 118.1 & 10.8 & 230.0 & 23.5 & 28.3 & 17.1 \\
\hline
\end{tabular}

Table 3. The industrial condition of each county district in Jinan

\begin{tabular}{|l|c|c|c|c|}
\hline Counties & $\begin{array}{c}\text { fixed investments(the } \\
\text { hundred million ) }\end{array}$ & $\begin{array}{c}\text { Scale above } \\
\text { industrial } \\
\text { added value }\end{array}$ & $\begin{array}{c}\text { The main business } \\
\text { income of the industries } \\
\text { over the scale(the } \\
\text { hundred million })\end{array}$ & $\begin{array}{c}\text { Total industrial profits } \\
\text { above scale(the hundred } \\
\text { million ) }\end{array}$ \\
\hline
\end{tabular}




\begin{tabular}{|c|c|c|c|c|c|c|c|}
\hline & $\begin{array}{c}1-12 \\
\text { month }\end{array}$ & $\begin{array}{c}\text { The } \\
\text { cumulative } \\
\text { year-on- } \\
\text { year\% }\end{array}$ & $\begin{array}{c}\text { The } \\
\text { cumulative } \\
\text { year-on-year\% }\end{array}$ & $\begin{array}{c}1-12 \\
\text { month }\end{array}$ & $\begin{array}{c}\text { The } \\
\text { cumulative } \\
\text { year-on- } \\
\text { year\% }\end{array}$ & $\begin{array}{c}1-12 \\
\text { month }\end{array}$ & $\begin{array}{c}\text { The } \\
\text { cumulative } \\
\text { year-on- } \\
\text { year } \%\end{array}$ \\
\hline Total & 3974.3 & 13.7 & 7.31 & 5722.6 & 7.31 & 368.6 & 12.23 \\
\hline $\begin{array}{c}\text { Lixia } \\
\text { District }\end{array}$ & 248.9 & 14.3 & 5.84 & 289.3 & -6.65 & 19.7 & 130.50 \\
\hline $\begin{array}{c}\text { Shizhong } \\
\text { District }\end{array}$ & 217.2 & 12.3 & 16.37 & 430.5 & 12.84 & 14.1 & 43.82 \\
\hline $\begin{array}{l}\text { Huaiyin } \\
\text { District }\end{array}$ & 268.7 & 4.9 & 4.35 & 164.8 & 1.54 & 14.0 & 28.86 \\
\hline $\begin{array}{c}\text { Tianqiao } \\
\text { District }\end{array}$ & 169.4 & -13.7 & 9.74 & 58.1 & 0.40 & -4.43 & - \\
\hline $\begin{array}{c}\text { Licheng } \\
\text { District }\end{array}$ & 594.8 & 16.6 & 0.75 & 591.0 & 3.14 & 32.38 & -15.97 \\
\hline $\begin{array}{l}\text { Changqing } \\
\text { District }\end{array}$ & 250.7 & 3.2 & 2.11 & 173.6 & -7.54 & -2.03 & - \\
\hline $\begin{array}{l}\text { Pingyin } \\
\text { County }\end{array}$ & 248.3 & 7.6 & 11.56 & 357.5 & 8.72 & 40.7 & 14.61 \\
\hline $\begin{array}{l}\text { Jiyang } \\
\text { County }\end{array}$ & 305.8 & 16.3 & 6.87 & 491.5 & 4.10 & 52.7 & 3.44 \\
\hline $\begin{array}{c}\text { Shanghe } \\
\text { County }\end{array}$ & 127.0 & 10.9 & 6.00 & 178.8 & -2.49 & 8.5 & 5.86 \\
\hline $\begin{array}{c}\text { Zhangqiu } \\
\text { District }\end{array}$ & 676.2 & 20.0 & 11.50 & 1852.2 & 12.35 & 125.3 & 13.96 \\
\hline $\begin{array}{c}\text { High-tech } \\
\text { zone }\end{array}$ & 684.8 & 18.0 & 8.31 & 1018.4 & 11.26 & 64.5 & 17.79 \\
\hline
\end{tabular}




\section{Conclusion}

The many factors influencing the development of dry port should be taken into consideration in the site selection. It is easy to have the benefit back effect and not get the best development benefit. In the long-term view of the development of dry port, a method of qualitative and quantitative combination should be adopted to locate the dry port. Considering the population, economy, transportation, industry and other conditions of various counties and districts in Jinan, it is suggested that dry port should be located in the district.

\section{References}

1. Roso.V., Philippe Leveque, Dry Port Concept for Seaport Inland Access with Inter-modal Solutions, [Master Thesis] for the Department of Transportation and Logistics, Sweden Chalmers University of Technology,2002.

2. Woxenius,J., Roso.V., The Dry Port Concept Connecting Seaports with Hinterland by Rail, the ICLSP

Conference,China,Dalian,September,2004:22-26.

3. Rutten,B.C.M., The Design of Terminal Network for Intermodal Transport, Transport Logistics, 1998,1(4):279-298.

4. Ballis.A.,Golias.J.,Comparative Evaluation of Existing and Innovative Rail Road Freight Transport Terminals, Transportation Research,2002,36:593611.nagement: a state-ofthe-art literature review. International Journal of Management Reviews 2007;9(1):53-80. 